\title{
Inventory and Morphological Characterization of Durian (Durio Zibethimus) in Langkahan and Sawang Sub-District of North Aceh Indonesia
}

\author{
Rd. Selvy Handayani \\ Agriculture Faculty, Universitas Malikussaleh, Aceh Utara, Indonesia \\ Ismadi \\ Agroecotechnology Laboratory of Agriculture Faculty, Universitas Malikussaleh, \\ Aceh Utara, Indonesia
}

\begin{abstract}
Purpose - The purpose of this study was to invent morphological North Aceh durian data as germplasm information.

Methodology - The research was conducted at Langkahan and Sawang, North Aceh Region, from March to August 2014. The material used was the durian plant that should be 20 years and preferred by the local community. Exploration as the first step of experiment was done by purposive sampling. Identification was done on the source of durian germplasm. The source of durian germplasm as the experimental object was observed for its growth and morphology. Data analysis for morphological characteristics was done by using NTSYSpc (Numerical Taxonomy and Multivariate Analysis) NTSYSpc versi 2.02.

Originality - The results showed that there were 25 accessions superior durian in Langkahan and 26 accessions superior durian in Sawang. They had different characters in the vegetative parts of the plant. The durian coefficient value of similarity in Langkahan ranged from 0.33 to 0.94 , while in Sawang, it ranged from 0.24 to 0.86 . The diversity of the morphological character in superior durian of Langkahan and Sawang was seen from the qualitative character (surface and color of bark, crown shape, top surface color of leaves, and leaf shape) and quantitative character (plant height, stem diameter, crown diameter, length, width, and leaf area).
\end{abstract}

Keywords Accessions, diversity, germplasm, morphology

All papers within this proceedings volume have been peer reviewed by the scientific committee of the Malikussaleh International Conference on Multidisciplinary Studies (MICoMS 2017).

The research was funded by the Ministry of Research, Technology, and Higher Education of the Republic of Indonesia through a Hibah Bersaing Grant program in 2014.

(C) Rd. Selvy Handayani, Ismadi. Published in the Emerald Reach Proceedings Series. Published by Emerald Publishing Limited. This article is published under the Creative Commons Attribution (CC BY 4.0) licence. Anyone may reproduce, distribute, translate and create derivative works of this article (for both commercial and non-commercial purposes), subject to full attribution to the original publication and authors. The full terms of this licence may be seen at http://creativecommons.org/ licences/by/4.0/legalcode

Inventory and Morphological Characterization

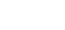




\section{Proceedings of 1. Introduction}

MICoMS 2017 Durian is the top commodity of fruit sub-sector in Aceh province (Bank Indonesia Aceh and LPPM Unimal, 2012), so it has a great profit opportunity to durian farming. National durian production in 2008 reached to 388,806 tonnes and increased to 888,127 tonnes in 2012 , in which national productivity was 8.09 tonnes/ha. Now a days Indonesia's export value of durian is with a total amount of only $2,929 \mathrm{~kg}$ or US $\$ 4,511$, while the import value is higher than export value such 20,638,608 $\mathrm{kg}$ or US\$30,022,830 (Deptan, 2012).

Different types of durian fruit from Aceh apparently have diversity of properties, such as morphology and fruit quality. This difference included that fruit and plant give specifically unique properties. It enriches durian fruit collection of Aceh durian. There are approximately many species of plants that have not been discovered and cultivated.

Those recent days, there is no research related to exploration and mapping production of durian production area. Beside that the inventory of durian morphology and molecular characterization is not done yet. Furthermore information can be used to know superior properties of these plants.

Exploration is needed to enrich genetic diversity of a germplasm collection. Enrichment of germplasm collection is lied down on collection of genetic diversity and intensity of accessing durian. For example, high population diversity is occurred in crops pollinated durian. So that sampling of durian is directed to generate the superior durian in sampling region.

Sources of germplasm obtained from the exploration stage are used for identifying the plant. Identification of plant is the activity of characterizing the durian plant properties. Initial identification could be done based on morphological properties of plant (Swasti, 2007). Plant identification based on morphological markers was used specially as initial information of genetical diversity of plant. Identification according morphological characterization was also important to be done, as plant diversity not only depends on genetic variation but also morphology variation (Campos et al., 2005).

This research will discuss about morphological properties of Aceh durian plant through exploration and identification of durian plant. The aim of this research is to gain North Aceh durian phenotype characteristics which have high potential of quality. The research is expected to exhibit the potential of Aceh durian and as the basic information for protecting Aceh durian from the thread.

\section{Methodology}

\subsection{Time and place}

The experiment was aimed to analyze the characterization of Aceh Durian. This experiment was conducted at Sawang, Langkahan, Buluh Blang Ara, and Paya Bakung District, North Aceh region. This experiment was also done at Agroekoteknologi Laboratory Agriculture Faculty Malikussaleh University from March to December 2014.

\subsection{Material and tools}

The material used was the durian plant that should be 25 years and preferred by local community. The equipments of this research were measurement tools, vernier calipers, and haga altimeter.

\subsection{Procedures}

The procedure of this research consists of exploration and identification of durian characteristics. Exploration as the first step of experiment was done by purposive sampling. Purposive sampling was carried out by measurement and observation on to durian plant in 
which the data were primary data. While the secondary data were obtained by interviewing to the owner of durian and agriculture department. Identification was done on source of durian germplasm. The source of durian germplasm as the experimental object was observed for its growth and morphology.

Inventory and Morphological Characterization

\subsection{Data analysis}

Data analysis for morphological characteristics was done by using NTSYSpc (Numerical Taxonomy and Multivariate Analysis) NTSYSpc versi 2.02 (Rohlf, 1998). Each characteristic was divided into sub-characteristics which shows the difference. The difference would be altered to binary data. Significant sub-characteristics would be marked as 1 and non-significant sub-characteristic would be marked as 0 . Furthermore, the data were grouped using cluster analysis with SHAN method in NTSYSpc program 2.02 version.

\subsection{Observation}

The result of plant exploration was characterized initially by its properties, such as plant age, plant source, plant height, stem radian, crown width, plant shape, and plant branching. Furthermore, another property of plant was branch location, stem color, stem condition, and stem shape. Characteristics of leaf were also observed through leaf location, leaf color, leaf edge, leaf surface, color of top leaf surface, color of bottom leaf surface, and leaf position.

\section{Result and discussion}

The exploration result at Langkahan and Sawang sub-districts showed many types of Durian accessions which were favored by people. The inventarization and characterization activities of durian plant had been done at several villages in Langkahan and Sawang. Superior durian trees obtained from the exploration consist of 25 accessions in Langkahan and 26 accessions in Sawang. The morphological characteristics of the trunk and the crown of superior durian tree in Langkahan and Sawang sub-districts of North Aceh are presented in Table 1 while the morphological characteristics of the superior durian leaf in Langkahan and Sawang sub-districts of North Aceh are presented in Table 2.

Table 1 shows that the accessions of durian tree height range from 15.26 to $50.23 \mathrm{~m}$. This is due to the difference in the durian tree life where it was not planted simultaneously (20135 years). The difference in plant height is also influenced by environmental factors such as sunlight. Durian trees in Langkahan and Sawang sub-district were not planted in monoculture but were mostly planted in polyculture. Furthermore, the planting of the tree does not have the right spacing. Those problems cause the durian trees to be shaded and, therefore, their growth will be prolonged due to the influence of etiolation. Durian trees can grow approximately up to 200 years, and the durian trunks will continue to grow to the limit of his life. Durian tree height ranges from 20 to $83 \mathrm{~m}$, although it can even reach $50 \mathrm{~m}$ (Wiryanta, 2010).

The characters of the trunk and crown also show differences in the qualitative data such as surface of the trunk, color of the trunk, crown shape, and branching patterns. These indicate that there are differences in morphological properties of plantation in the two subdistricts. The surface and the color of the trunks have differences due to the age and origin of the different plant seeds. The seeds of durian trees came from different tree types and the elders are often unknown.

Other differences are seen in the top surface color of the leaves and the leaves shape (Table 2). The color of the top surface of durian trees of Langkahan is green and dark green, while in Sawang, green are more dominant than light green and dark green. The leaves color of a plant species may change according to its growing state and is closely related to water 
Proceedings of and food supplies and irradiation (Tjitrosoepomo, 2005). The bottom side of the durian tree MICoMS 2017 leaves has a different color from its top surface where it was predominantly green. The color of the bottom surface durian leaves in both sub-districts is golden.

From the observation of vegetative parts of durian, both qualitatively and quantitatively showed a high degree of diversity. In addition to that, the visual observation of the leaves showed that there was a diversity but it was not very significant than the quantitative

\section{4} observations. However, the description of the observations alone was not sufficient to prove the degree of similarity between trees in general or in particular. Therefore, the level of plant similarity needs to be tested using the analytical method.

Clustering analysis is a useful statistical technique to classify objects or variables into groups where each object or variable is formed adjacent. Clustering analysis can group all data to form a dendogram. The similarity relation is higher when the value of similarity is close to number 1 . The value of similarity index or equality index is used to compare the similarities found between one sample with another. If the value is close to $0.0(0 \%)$, then the

\begin{tabular}{lllcc}
\hline & & & \multicolumn{2}{c}{ Amount/Range } \\
No. & \multicolumn{1}{c}{ Character } & Sub-Character & Langkahan (25 Accessions) & Sawang (26 Accessions) \\
\hline 1 & Tree height $(\mathrm{m})$ & - & $22.58-48.38$ & $15.26-50.23$ \\
2 & Trunk circumference $(\mathrm{m})$ & - & $1.67-3.80$ & $7.60-3.20$ \\
3 & Number of branches & - & $11.00-16.00$ & $5.00-25.00$ \\
4 & Trunk shape & Circle & 25.00 & 26.00 \\
5 & Trunk surface & Slightly rough & 4.00 & 1.00 \\
& & Rough & 14.00 & 16.00 \\
& & Very rough & 7.00 & 9.00 \\
6 & Trunk color & Brown & 6.00 & 7.00 \\
& & Gray & 8.00 & 9.00 \\
& & Grayish brown & 11.00 & 10.00 \\
7 & Crown diameter (m) & - & $11.00-22.00$ & $10.00-26.00$ \\
8 & Crown shape & Pyramidal & 5.00 & 6.00 \\
& & Semicircular & 11.00 & 2.00 \\
& & Oblong & 4.00 & 6.00 \\
& & Irregular & 2.00 & 12.00 \\
9 & Branching pattern & Horizontal & 14.00 & 8.00 \\
& & Upright & 8.00 & 4.00 \\
& & Irregular & 3.00 &
\end{tabular}

Table 1.

Character of Trunks and Crowns of the Superior Durian in Langkahan and Sawang SubDistricts of North Aceh District

\begin{tabular}{lllcc}
\hline & & & \multicolumn{2}{c}{ Amount/Range } \\
No. & \multicolumn{1}{c}{ Character } & Sub-Character & Langkahan (25 Accessions) & Sawang (26 Accessions) \\
\hline 1 & Leaves length $(\mathrm{cm})$ & - & $11.20-17.00$ & $7.00-14.05$ \\
2 & Leaves width $(\mathrm{cm})$ & - & $3.00-6.50$ & $2.80-4.60$ \\
3 & Color of upper surface & Green & 11.00 & 19.00 \\
& & Dark green & 14.00 & 1.00 \\
& & Light green & 0 & 6.00 \\
4 & Color of lower surface & Golden & 25.00 & 26.00 \\
5 & Leaves shape & Oval & 9.00 & 19.00 \\
& Llliptic & 16.00 & $20.64-66.71$ \\
& Leaves area $\left(\mathrm{cm}^{2}\right)$ & - & $40.27-76.04$ &
\end{tabular}


similarity level is low and if the value is close to $1.00(100 \%)$, then the similarity of the community between samples is high (Khanna, 2015).

The amounts of the diversity of superior durian trees obtained in Langkahan sub-district are 25 accessions and in Sawang are 26 accessions. Accession classification of durian trees can be done based on the morphological nature of the vegetative part of the plant in both sub-districts. Dendrograms that describe the coefficient of similarity of superior durian trees in Langkahan and Sawang are presented in Figures 1 and 2.

Figure 1 shows that the durian trees in Langkahan sub-district have a high diversity level. At the similarity level of 0.33 (33\%), the Langkahan durian tree was divided into two clusters. The first cluster consisted of 7 accessions and the second cluster with 18 accessions.

The similarity of the plant was said to be low if the coefficient value of the similarity was less than $0.6(60 \%)$, otherwise the similarity was said to be high if the similarity coefficient value approaches above $0.6(60 \%)$ or approaches number $1.00(100 \%)$ (Cahyarini et al., 2004). At the value of similarity coefficient 0.6 , the superior durian plant of Langkahan was
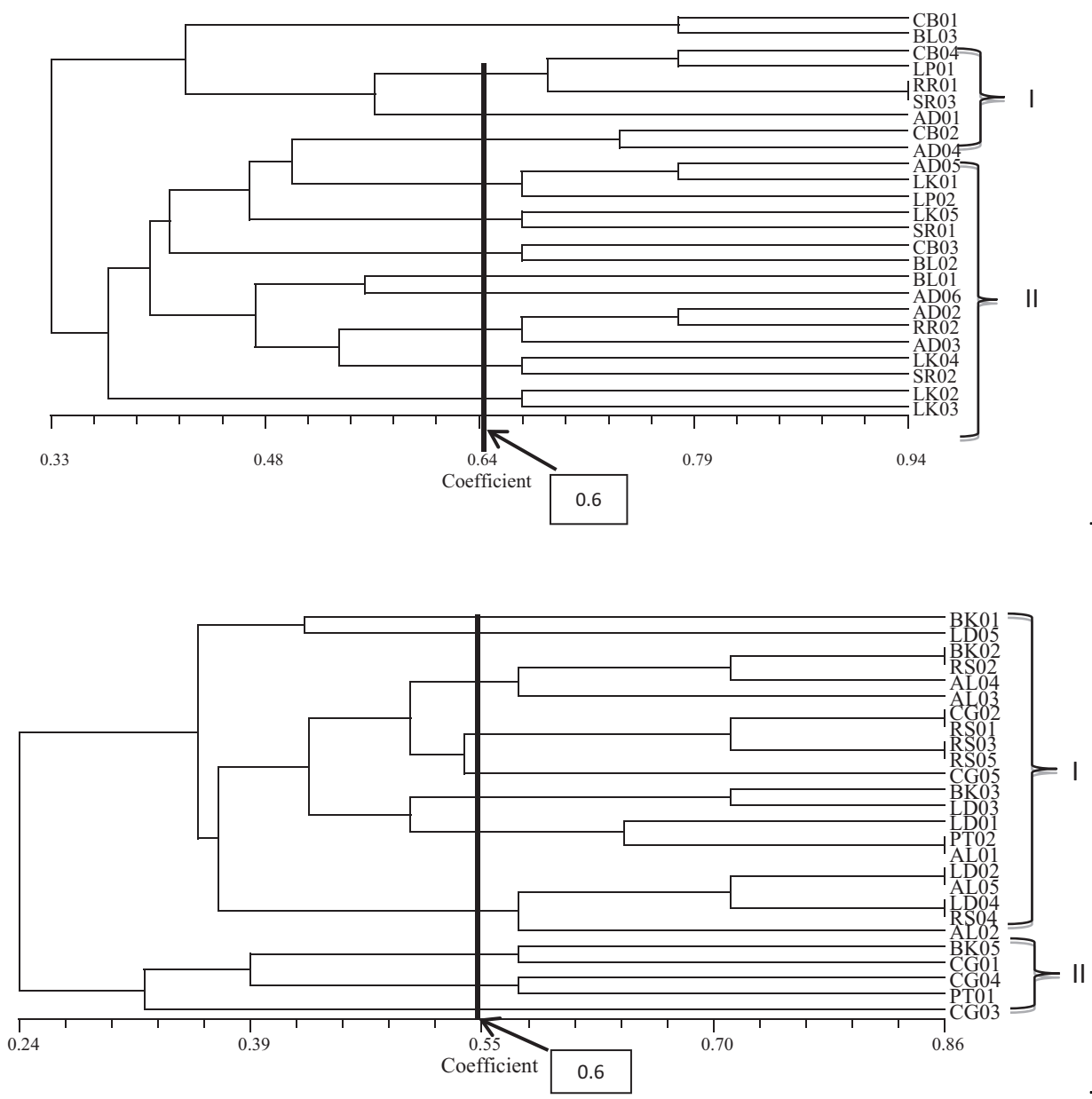

Inventory and Morphological Characterization

605

Figure 1.

Classification of 25

Accessions of

Superior Durian Trees in Langkahan, North Aceh
Figure 2.

Classification of 26

Accessions of the Superior Durian Trees in Sawang, North Aceh 
Proceedings of MICoMS 2017 divided into many clusters which were 12 . Trees that had the highest similarity value of 0.94 $(94 \%)$ are RR01 and SR03 accession. Trees with the lowest similarity were accessions of AD01, BL01, and AD06.

Figure 2 shows that durian plants in Sawang sub-district had high diversity level. At the similarity level of $0.24(24 \%)$, Langkahan durian tree was divided into two clusters. The first cluster consists of 19 accessions and the second cluster was with 5 accessions. At the value of similarity coefficient of 0.6 , Sawang durian was divided into many clusters which were 15. There were some trees that had the highest similarity with the level of $0.86(86 \%)$ which are BK02 with RS02, CG02 with RS01, RS03 with RS05, PT02 with AL01, LD02 with AL05, and LD04 with RS04. Plants with the lowest similarity were accessions of AD01, BL01, and AD06.

Differences in the degree of similarity and dissimilarity of plants are due to morphological differences between the accessions qualitative and quantitative. Differences in morphological characters among durian trees are also influenced by genetic and environment. Plants need a certain environmental state that is the optimum environment conditions to express its genetic completely (Sitompul and Guritno, 1995).

The weakness of morphology marker is influenced by the development of plant and environmental development. Sometimes it is difficult to distinguish the observed genotype, because it looks the same morphologically, although the genotypes are actually different. This is due to the covering of the recessive characters by the dominant characters (Bakhtiar, 2002).

Morphological characterization is considered less accurate because it is influenced by plant growth stage and environmental factors. However, morphological characterization is still needed as an early stage to find the genetic diversity of plants and to complete the results of biochemical and molecular analyzes. Morphological characterization is also important, since the morphological diversity in certain plants often does not depend on its genetic diversity. This can be seen from the low cofenetic correlations between morphological and molecular dendrograms (Koehler-Santos et al., 2003; Campos et al., 2005).

High diversity can be analyzed through both qualitative and quantitative characters (Pangestu et al., 2014). The high level of diversity of durian tree is due to the presence of selfincompatibility in it, so that the cross-pollination character is very strong (Bumrungsri et al., 2009; Indriyani et al., 2012). The low level of plant similarity indicates that the plant group has a high diversity that represents a large genetic distance. The large genetic distance indicates that the kinship relationship has quite a distance (Siregar and Olivia 2012). The lower the value of similarity (the longer the distance level) indicates the fewer similarities between the variables which means the kinship is further (Wahyudi, 2007) and vice versa.

The analyses of plant kinship relationship through morphological properties play a big role in plant development. Furthermore, it can also be used in applied fields such as plant breeding (Ihsan et al., 2012; Hadi et al., 2014), tissue culture (Lizawati et al., 2012; Zulkarnain et al., 2013), and the research source of alternative food crops. The increasing amount of genetic resources strongly support the plant breeding attempts (Lestari et al., 2016), so that the development and preservation of crops can be done.

\section{Conclusion}

(1) The number of superior durians was 25 accessions (Langkahan) and 26 accessions (Sawang).

(2) The durian coefficient value of similarity in Langkahan ranged from 0.33 to 0.94 , while in Sawang, it ranged from 0.24 to 0.86 . 
(3) The diversity of morphological character in superior durian of Langkahan and Sawang was seen from the qualitative character (surface and color of bark, crown shape, top surface color of leaves, and leaf shape) and quantitative character (plant height, stem diameter, crown diameter, length, width, and leaf area).

Inventory and Morphological Characterization

\section{References}

Bakhtiar. (2002). Analisis keragaman genetik gladiol dengan penanda RAPD dan evaluasi ketahanan turunan dari beberapa kombinasi silangan terhadap Fusarium. Graduate School Thesis, Institut Pertanian, Bogor, Indonesia.

Bank Indonesia Aceh, LPPM Unimal. (2012). Penelitian pengembangan komoditas/produk/jenis usaha (KPJu) unggulan usaha mikro dan menengah (UMKM) Provinsi Aceh. BI Aceh dan LPPM Unimal, Indonesia.

Bumrungsri S., Sripaoraya, E., Chongsiri, T., Sridith, K., Racey, P.A. (2009). "The pollination ecology of durian (Durio zibethinus, Bombacaceae) in Southern Thailand”. J. Tropical Ecology. Vol.25, pp. 85-92.

Cahyarini, R.D., Yunus, A. and Purwanto, E. (2004). "Identifikasi Keragaman Genetik Beberapa Varietas Lokal Kedelai di Jawa Berdasarkan Analisis Isozim Agrosains”. Agrosains, Vol. 6, No. 2, pp. 79-83.

Campos, E.T., Espinosa, M.A.G., Warburton, M.L., Varela, A.S. and Monter, A.V. (2005). "Characterization of mandarain (Citrus spp.) using morphological and AFLP markers". Intersciencia, Vol. 11, pp. 687-692.

Deptan. (2012). Pertanian. Available: http://hortikultura.deptan.go.id/? q=node/327 [accessed 12 March 2013].

Hadi, S.K., Purnamaningsih, L.S. and Ashari S. (2014). "Keragaman dan pendugaan nilai kemiripan 18 tanaman durian hasil persilangan Durio Zibethinus dan Durio Kutejensis". Jurnal Produksi Tanaman, Vol. 2, No. 1, pp. 80-85.

Ihsan, F., Sukarmin and Koswara, E. (2012). "Teknik persilangan durian untuk perakitan varietas unggul baru”. Buletin Teknik Pertanian, Vol. 17, No. 1, pp. 14-17.

Indriyani, N.L.P., Hadiati, I., Nasution, S., Sudjijo, E. and Irawati, Y. (2012). "Maternal and Paternal Effect on the Characters of durian (Durio zibethinus Murr.) Fruit from Cross-pollination". Journal of Fruit and Ornamental Plant Research, Vol. 20, No. 2, pp. 23-33.

Koehler-Santos, P., Dornelles, A.L.C., de Freitas, L.B. (2003). "Characterization of mandarin citrus germplasm from Southern Brazil by morphological and molecular analyses”. Pesq. agropec. bras. Vol. 38, No. 7, pp. 797-806.

Khanna, P. (2015). Keragaman Genetik Menggunakan Marka Molekuler Random Amplified Polymhorpic DNA (RAPD) dan Aktivitas Antioksidan Sirsak (Annona muricata L.) di Jawa Barat. Graduate School Thesis. Institut Pertanian Bogor Indonesia

Lestari, P., Wikan, D., Rosdianti, I. and Sabran, M. (2016). "Morphological Variability of Indonesian Rice Germplasm and the Associated SNP Markers". Emirates Journal of Food and Agriculture, Vol. 28, No. 9, pp. 660-670.

Lizawati, Neliyati and Desfira, R. (2012). "Induksi kalus eksplan daun Durian (Durio zibethinus Murr. cv. Selat Jambi) pada beberapa kombinasi 2,4-D dan BAP”. Bioplantae. Vol. 1, No. 1, pp. 23-29.

Pangestu, H.F., Azis, S.A. and Sukma, D. (2014). "Karakterisasi morfologi anggrek Phalaenopsis Hibrida”. Jurnal Hortikultura (Indonesia), Vol. 5, No. 1, pp. 29-35.

Rohlf, F.J. (1998). User Guide of NTSYSpc Numerical Taxonomy and Multivariate Analysis System. Department of Ecology and Evolution State University of New York. New York. 
Proceedings of Siregar, U.J. and Olivia, R.D. (2012). "Keragaman Genetik Populasi Sengon (Paraserianthes falcataria MICoMS 2017 (L) Nielsen) pada Hutan Rakyat di Jawa Berdasarkan Penanda RAPD”. Jurnal Sivikultur Tropika", Vol. 3, pp. 130-136.

Sitompul, S.M. and Guritno, B. (1995). Analisis Pertumbuhan Tanaman. Gajah Mada University Press, Yogyakarta, Indonesia.

608

Swasti, E. (2007). Pengantar Pemuliaan Tanaman. Agriculture Faculty, Universitas Andalas, Indonesia.

Tjitrosoepomo, G. (2005). Morfologi Tumbuhan. Gajah Mada University Press, Yogyakarta, Indonesia

Wahyudi, A.J. (2007). "Memperkenalkan cluster Analisis of variables malam minitab 11.12 untuk Kajian Filogeni suku-suku Krustaseae (Brachyura)”. Jurnal Oseana, Vol. 32, No. 3, pp. 21-36.

Wiryanta, B.T.W.. (2010). Panen Durian di Perkarangan Rumah. PT. Agromedia Pustaka, Jakarta.

Zulkarnain, Neliyatiand, Lizawati. (2013). "Callus Proliferation from Immature Leaf Explants of Durian (Durio zibethinus Murr. cv. Selat) with the Addition of Picloram and BAP”. Journal of Horticulture (Indonesia), Vol. 4, No. 3, pp. 107-114.

\section{Corresponding author}

Selvy can be contacted at selvy@unimal.ac.id 